\title{
Short-term mortality in post-emergent larval capelin Mallotus villosus. II. Importance of food and predator density, and density-dependence*
}

\author{
C. T. Taggart ${ }^{1, *}$, W. C. Leggett ${ }^{2}$ \\ ${ }^{1}$ Department of Biology, Dalhousie University, Halifax, Nova Scotia B3H 4J1, Canada \\ ${ }^{2}$ Department of Biology, McGill University, 1205 Avenue Docteur Penfield, Montreal, Québec H3A 1B1, Canada
}

\begin{abstract}
Analysis of post-emergent larval capelin Mallotus nillosus density in a small embayment in eastern Newfoundland during 1981 to 1983 demonstrated that as sampling scales approached those relevant to the larvae (ca $2 \mathrm{~h}, 200$ to $400 \mathrm{~m}$ ) the degree of positive association between microzooplankton and larvae decreased. Forty sequential estimates of post-emergent larval mortality were not significantly correlated with either the density of edible microzooplankton (90 to $130 \mu \mathrm{m}$ size-classes), the density of potential predators (chaetognaths and jellyfish), or the density of other macrozooplankton. Correlations with potential predator densities, while insignificant, were positive. We suggest that positive correlations between predator density and mortality are more likely to occur when analysing field data that is collected near-instantaneously because of the near-instantaneous effect predators have on population losses relative to the longer-term cumulative effects that result from food limitation (starvation). There was no significant relation between larval density and larval mortality and the hypothesis of density-dependent short-term mortality in post-emergent larvae was rejected.
\end{abstract}

\section{INTRODUCTION}

In his expansion of Hjort's $(1914,1926)$ larval mortality hypothesis, Cushing $(1966,1972)$ proposed that recruitment in marine fish was a function of larval food availability and competition among larvae for food. Many authors have assumed or hypothesized that: (1) starvation is a key determinant of recruitment; (2) during early larval development food must be highly concentrated; and (3) survival is a density-dependent function of larval density and food concentration (Blaxter \& Hempel 1963, Cushing 1966, 1968, 1972, 1974 a, b, Cushing \& Harris 1973, Harding \& Talbot 1973, Jones 1973, Jones \& Hall 1974, May 1974, Harris 1975, Lasker 1975, Arthur 1976, Hunter 1976, Nelson et al. 1977, Shepherd \& Cushing 1980, Hunter 1981).

Several studies have demonstrated that recruitment variation is correlated with a variety of abiotic factors that influence egg and larval survival (Chadwick et al.

Contribution to the programme of GIROQ (Group interuniversitaire de recherches océanographiques du Québec)

- Correspondence to: Bedford Institute of Oceanography, Box 1006, Dartmouth, Nova Scotia B2Y 4A2, Canada
1977, Leggett 1977, Nelson et al. 1977, Bakun \& Parish 1980, Bailey 1981, Crecco \& Savoy 1984, Leggett et al. 1984, Sinclair et al. 1985, Peterman \& Bradford 1987). However, there is little direct field evidence that larval mortality is a function of biotic factors, particularly food abundance, and the indirect evidence is conflicting. While starving, emaciated, and dead larvae have been found in the ocean (Soleim 1942, Shelbourne 1957. Wiborg 1976, O'Connell 1980, Theilacker 1986), other researchers have found no evidence of starvation, no period that is detrimental to survival, and no inter- or intra-annual variation in larval condition (Vilela \& Zijlstra 1971, Walline 1985). The co-occurrence of larvae and their prey is frequently well defined (Blaxter 1965, O' Connell 1980, Frank \& Leggett 1982, Fortier \& Leggett 1984), but is equally not well defined (Grauman 1973, Iles \& Sinclair 1982, Gadomski \& Boehlert 1984, Houde \& Lovdal 1984, O'Boyle et al. 1984, Sinclair et al. 1985, Ware \& Lambert 1985, Anderson \& Gardner 1986, Taggart \& Leggett 1987a). Furthermore, the interpretation of the results of some studies concerned with the sympatry of larvae and their food has recently been challenged (Frank 1988). Finally, food levels ensuring high survival are often greater than 
(LeBrasseur et al. 1969, O'Connell \& Raymond 1970. Hunter 1972, Houde 1978, Lasker 1975, Bjorke 1976 , Rosenberg \& Haugen 1982, Wroblewski 1984), or less than (Dementyeva 1958, Murphy 1961, Waldmann 1961, Cushing 1983, Peterson \& Ausubel 1984, Houde $\&$ Lovdal 1985) those found at sea

The evidence supporting density-dependent larval mortality is equally inadequate (Ware 1975, Rothschild 1986), partly because this form of population regulation during early larval development, if it exists, is obscured by the statistically dominant density-independent effects of abiotic factors (Sissenwine 1984). Moreover, researchers are seen to have been content to state the existence of density-dependence rather than measure it' (Cushing 1974a, p. 408). Hempel (1963, 1965) outlined various factors to be considered when studying the concept of density-dependent mortality in larval fishes (density and size of larvae relative to their prey, dispersion of larvae relative to their prey, relative residence time of larvae and their prey in a water mass etc.), yet they have received remarkably little attention (Jones 1973 is an exception). Competition for food has been ruled out as a factor influencing mortality in some studies (Rosenthal \& Hempel 1971, Cushing 1983, Houde \& Lovdal 1985), yet in others there is the suggestion of both inter- and intra-specific competition for larval food (Fraser 1970, Möller 1980, Kane 1984, Frank 1986). Food availability obviously can affect larval mortality, but the form of the relationship between food availability and realized mortality remains uncertain as does the relationship between food availability and recruitment (May 1974, Leggett 1986).

In studying the population dynamics of larval capelin Mallotus villosus in eastern Newfoundland we have demonstrated that: (1) unbiased abundance estimates of larvae and other planktonic taxa can be obtained coincidently (Taggart \& Leggett 1984); and (b) biases in the estimates attributed to sampling design and larval behaviour can be taken into account (Taggart \& Leggett 1987a). In the companion paper (Taggart \& Leggett $1987 \mathrm{~b}$ ) we provide the results from a study designed to measure the abundance of larval capelin during the initial stages of oceanic drift which were used to derive multiple estimates of immigration-emigration corrected short-term mortality. In this paper we address 3 primary questions: (1) Are post-emergent capelin larvae consistently associated with edible microzooplankton? (2) Is the variation in short-term larval mortality explained by variation in the density of microzooplankton (potential food)? (3) Is larval mortality related to larval density? Although our sampling protocol was not specifically designed to do so, we secondarily investigated the relationship between larval mortality and the density of macrozooplankton (potential predators)

\section{MATERIALS AND METHODS}

The study was conducted at Bryants Cove $\left(47^{\circ} 40.5^{\circ}\right.$ $\left.\mathrm{N}, 53^{\circ} 11.0^{\circ} \mathrm{W}\right)$, Conception Bay, Newfoundland. A total of 1634,283 , and 1622 zooplankton collections were made in Bryants Cove between June and August of 1981, 1982, and 1983 respectively. Collections were made at least daily (with few exceptions) to depths of $9 \mathrm{~m}$ at a suite of 6 or 16 stations in Bryants Cove using a customized plankton pump and an $80 \mu \mathrm{m}$ mesh net (Taggart \& Leggett 1984). Details of the study site, sampling design, and sampling methods are provided in Taggart \& Leggett $(1987 \mathrm{a}, \mathrm{b})$.

All zooplankton collections were sorted for fish larvae and macrozooplankton. The 12 macrozooplankton classes removed and enumerated were capelin larvae, non-capelin larvae (mainly herring Clupea harengus), chaetognaths, jellyfish (mainly Rathkea, Bougainvillia, and Aglantha spp.), and larger individuals (>750 $\mu \mathrm{m})$ of hyperiid amphipods, crab zoea and megalops, euphausiids, Oikopleura sp., cyprid larvae, fish eggs and copepods. The remainder of each collection was filtered through a $750 \mu \mathrm{m}$ mesh sieve and the retained individuals were counted and removed. The fraction $<750 \mu \mathrm{m}$ was subsampled and 10 equivalent spherical diameter (esd) particle size-classes ( 75 to $394 \mu \mathrm{m}$ ) were enumerated with a TA-II Coulter Counter as in Taggart \& Leggett (1987a). Estimates of size-class biomass $\left(\mu \mathrm{gl}^{-1}\right)$ were made by multiplying the count in each size-class by the volume of each class assuming $1 \mathrm{~g} \mathrm{~cm}^{-3}$ density. In this paper the sum of the 90 to $394 \mu \mathrm{m}$ esd size-classes is termed 'total particles', and the sum of the 90 to $130 \mu \mathrm{m}$ esd potential prey classes (Taggart \& Leggett 1987a) is termed 'edible particles'. Chaetognaths and jellyfish were considered potential predators.

The bias-corrected abundance ( $N$ and $N E$ ) and daily and instantaneous mortality estimates $\left(M_{5}\right.$ and $\left.z_{5}\right)$ for capelin larvae, and rates of larval immigration from the beach in 1982 and 1983, were taken from Taggart \& Leggett (1987b). Nearshore water temperature data were collected in 1982 and 1983 with an Aanderaa RCM4 current meter moored at $4.5 \mathrm{~m}$ depth (Taggart \& Leggett 1987 a). Temperature records were not available for 1981.

Analysis. We performed correlation analyses on the density estimates of capelin larvae with zooplankton particle size-classes and with the density of the other plankton groups in all collections to assess small-scale associations between post-emergent larvae and their potential prey, and secondarily to identify patterns of association with other groups in the planktonic community, Significance was conservatively assessed $\left(\alpha_{0.01}\right)$ because of the large sample size. As the results of the analysis were influenced by temporal variability, we performed a correlation analysis between the 
density of capelin larvae and the density of edible particles collected during each sampling survey. Subsequently a similar analysis was performed with the effects of over-dispersion reduced by using the geometric average of the density estimates. A constant of 1.0 was added to all density estimates prior to the logarithmic transformation because of zero abundance for some groups in some collections. The correlation structure between the various groups and temperature in 1982 and 1983 was also examined to assess the influence of temperature, and hence water mass type, on community associations identified by Frank \& Leggett $(1982,1983 \mathrm{a})$.

We performed a correlation analysis of daily larval mortality $\left(\mathrm{M}_{5}\right)$ and instantaneous mortality $\left(\mathrm{z}_{5}\right)$ with the geometric average density of edible particles for each sampling survey interval in 1982 and 1983 to assess the relationship between larval mortality and the density of larval prey. The geometric average densities of the other plankton groups were also examined for significant correlations with larval mortality. There were no $M_{5}$ or $z_{5}$ estimates in 1981 (Taggart \& Leggett 1987b).

Density-dependent mortality was assessed first by examining the relationship between mortality and larval density, and second by employing the Varley \& Gradwell analytical technique (Varley \& Gradwell 1960, Varley et al. 1973, Southwood 1978). The latter requires a 3 -step series of regression analyses of measures of the target population density over the time interval between sequential sampling surveys $\left(t_{2}-t_{1}\right)$.
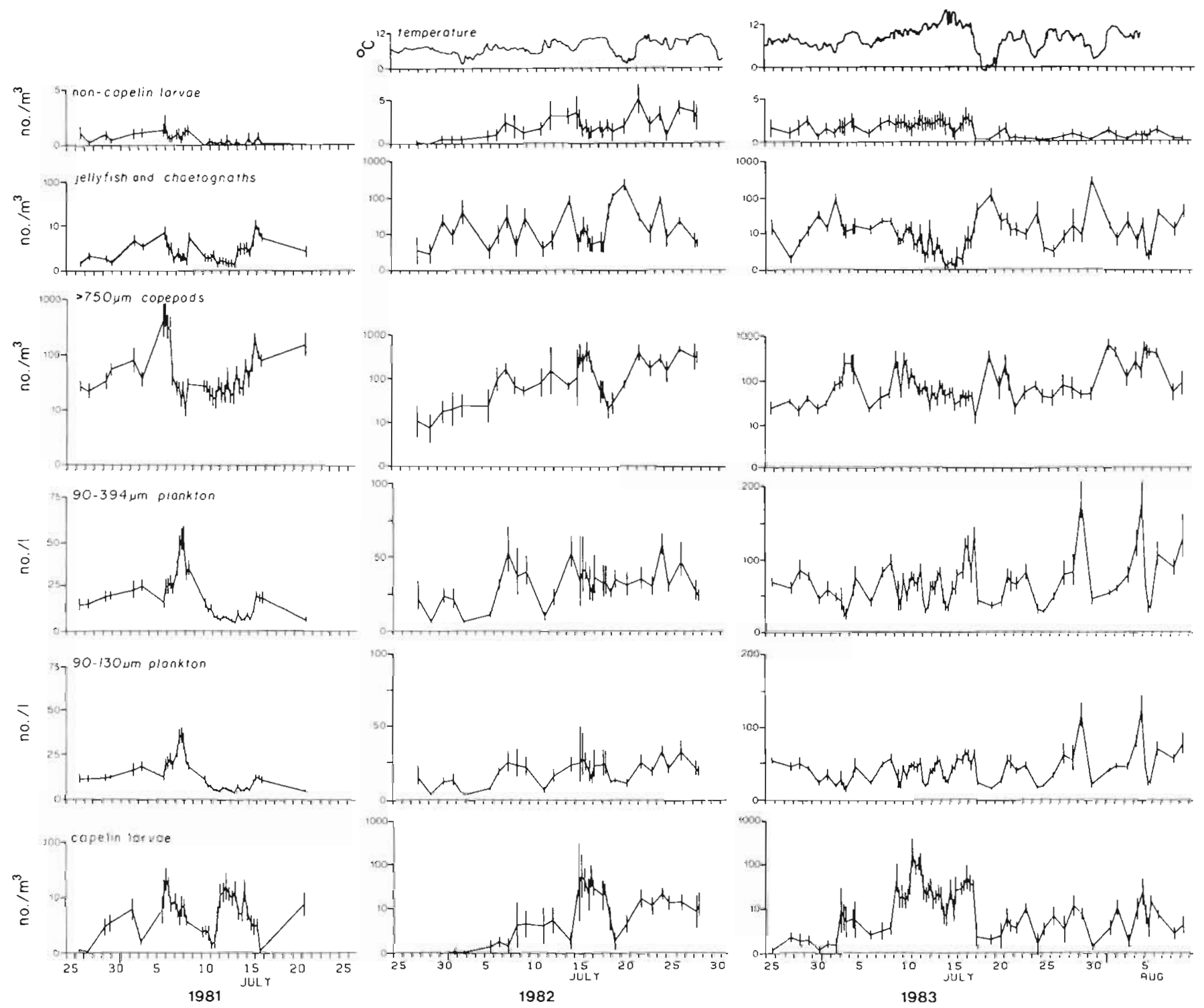

Fig. 1. Time series of average density ( $\pm 2 \mathrm{SE}$ ) of capelin larvae, edible plankton particles (90 to $130 \mu \mathrm{m}$ esd), total plankton particles (90 to $394 \mu \mathrm{m}$ ), copepods $>750 \mu \mathrm{m}$ chaetognaths and jellyfish, and non-capelin larvae in Bryants Cove in 1981 to 1983. Water temperature time series are provided for 1982 and 1983 
The first analysis is the regression of $\mathrm{k}$ on the logarithm of the immigration-emigration corrected larval density expected in the absence of mortality (NE) where:

$$
\mathrm{k}=\log \mathrm{NE}_{\mathrm{t}_{2}}-\log \mathrm{N}_{\mathrm{t}_{2}}
$$

and where $\mathrm{N}=$ observed larval density. Densitydependence is suspected if there is a statistically significant relation. However, as the 2 variates in the regression are not independent, $\log N$ must be regressed on $\log \mathrm{NE}$ and vice versa. Density-dependence is formally demonstrated if both regressions result in slopes ( $b$ and $b^{\prime}$ ) that are significantly different from 1.0, and both $b$ and $1 / b^{\prime}$ are $>1.0$ or $<1.0$ (Southwood 1978). As the time interval between sampling surveys ranged between 6 and $24 \mathrm{~h}$, the estimates of $\mathrm{N}$ were standardized to a $12 \mathrm{~h}$ interval by using the instantaneous mortality estimate $\left(z_{5}\right)$ from Taggart \& Leggett (1987b):

$$
\mathrm{N}_{\mathrm{t}_{2}}=\mathrm{NE}_{\mathrm{t}_{2}} \mathrm{e}^{\mathrm{Z}_{5}(12)}
$$

\section{RESULTS}

\section{Overview of major zooplankton groups}

The average density of post-emergent capelin larvae showed intra-annual variation of 1 to 2 orders of magnitude in each year (Fig. 1). The average annual density increased sequentially from 20 to $42 \mathrm{~m}^{-3}$ from 1981 to 1983 (Table 1). The average densities of edible particles ( 90 to $130 \mu \mathrm{m}$ esd) and total plankton particles (90 to $394 \mu \mathrm{m}$ esd) were less variable (Fig. 1). The magnitude and frequency of variations in these 2 sizeclass groupings increased sharply from 1981 to 1983.
The maximum density of both groups were similar in 1981 and 1982, but the averages in 1981 were ca $30 \%$ lower than in 1982 (Table 1). The density and biomass of edible and total particles also displayed a sequential annual increase. However, where the edible size-class represented 71 and $29 \%$ of the total density and biomass respectively in 1981, it represented only 63 and $16 \%$ respectively in 1982 and 1983.

The density of copepods in the $>750 \mu \mathrm{m}$ size-class exhibited intra-annual variations similar to those of capelin (Fig. 1), but annual averages were relatively constant (Table 1). The average densities of chaetognaths and jellyfish exhibited intra-annual fluctuations of nearly 3 orders of magnitude in both 1982 and 1983 (Fig. 1), and their average density was 7 to 9 -fold greater than in 1981 (Table 1). The density of noncapelin larvae was less variable within years (Fig. 1) and their annual averages showed no trend (Table 1).

An inspection of the time-series in Fig. 1 reveals associations between the density of several planktonic groups and variations in water temperature in 1982 and 1983. Capelin density and edible and total plankton particle size-class densities appeared to be positively associated with temperature and the density of jellyfish and chaetognaths appeared to be inversely related. These observations are consistent with earlier findings (Frank \& Leggett 1982, 1985, Taggart \& Leggett 1987 a).

\section{Small-scale associations}

Capelin larvae were significantly and positively correlated with the edible particle size-classes among all collections taken in the $3 \mathrm{yr}$ (Fig. 2). There was a

\begin{tabular}{|c|c|c|c|c|c|c|c|c|c|c|c|c|}
\hline \multirow[b]{2}{*}{ Plankton group } & \multicolumn{4}{|c|}{$1981(n=1634)$} & \multicolumn{4}{|c|}{$1982(\mathrm{n}=283)$} & \multicolumn{4}{|c|}{$1983(n=1622)$} \\
\hline & Av. & $\mathrm{SD}$ & Max & Min & Av. & $\mathrm{SD}$ & $\operatorname{Max}$ & Min & Av. & SD & Max & Min \\
\hline \multicolumn{13}{|l|}{ Density } \\
\hline Capelin larvae $\mathrm{m}^{-3}$ & 19.9 & 72.5 & 1365.2 & 0.0 & 34.7 & 102.8 & 981.2 & 0.0 & 41.6 & 125.2 & 3003.4 & 0.0 \\
\hline Non-capelin larvae $\mathrm{m}^{-3}$ & 0.4 & 3.7 & 147.6 & 0.0 & 1.5 & 3.4 & 48.4 & 0.0 & 1.0 & 1.7 & 16.3 & 0.0 \\
\hline Chaetognaths $\mathrm{m}^{-3}$ & 2.5 & 4.5 & 39.5 & 0.0 & 24.2 & 48.6 & 473.0 & 0.0 & 17.0 & 44.6 & 558.1 & 0.0 \\
\hline Jellyfish $\mathrm{m}^{-3}$ & 0.7 & 1.8 & 24.7 & 0.0 & 4.3 & 6.0 & 40.1 & 0.0 & 3.9 & 7.1 & 105.1 & 0.0 \\
\hline$>750 \mu \mathrm{m}$ copepods $\mathrm{m}^{-3}$ & 213.4 & 719.0 & 9700.2 & 0.0 & 229.2 & 261.6 & 1431.1 & 0.0 & 183.1 & 304.1 & 3715.3 & 1.7 \\
\hline $90 \mu \mathrm{m}$ particles $\mathrm{I}^{-1}$ & 5.8 & 6.0 & 102.7 & 0.1 & 9.1 & 7.8 & 83.6 & 0.6 & 17.4 & 9.9 & 106.2 & 1.4 \\
\hline $108 \mu \mathrm{m}$ particles $l^{-1}$ & 5.0 & 5.5 & 79.1 & 0.1 & 7.2 & 5.6 & 46.8 & 0.6 & 15.3 & 8.3 & 96.9 & 0.9 \\
\hline $130 \mu \mathrm{m}$ particles $1^{-1}$ & 3.4 & 3.6 & 47.1 & 0.1 & 5.3 & 4.2 & 37.5 & 0.6 & 11.8 & 6.9 & 85.1 & 0.5 \\
\hline Food particles $1^{-1}$ & 1.4 .2 & 14.9 & 228.9 & 0.3 & 21.6 & 17.3 & 167.8 & 2.0 & 44.5 & 24.2 & 284.1 & 2.9 \\
\hline Total particles $1^{-1}$ & 20.1 & 20.3 & 276.0 & 0.5 & 34.4 & 23.6 & 214.8 & 3.3 & 70.2 & 39.1 & 435.1 & 3.4 \\
\hline \multicolumn{13}{|l|}{ Biomass } \\
\hline $90 \mu \mathrm{m}$ particles $\left(\mu \mathrm{g} \mathrm{l}^{-1}\right)$ & 2.2 & 2.3 & 39.0 & 0.1 & 3.5 & 3.0 & 31.7 & 0.2 & 6.6 & 3.7 & 40.3 & 0.5 \\
\hline $108 \mu \mathrm{m}$ particles $\left(\mu \mathrm{g} \mathrm{l}^{-1}\right)$ & 3.3 & 3.6 & 52.3 & 0.1 & 4.8 & 3.7 & 30.9 & 0.4 & 10.11 & 5.5 & 64.0 & 0.6 \\
\hline $130 \mu \mathrm{m}$ particles $\left(\mu \mathrm{g} \mathrm{l}^{-1}\right)$ & 4.0 & 4.1 & 54.1 & 0.1 & 6.1 & 4.8 & 43.1 & 0.7 & 13.6 & 7.9 & 97.8 & 0.6 \\
\hline Food particles $\left(\mu \mathrm{g} \mathrm{I}^{-1}\right)$ & 9.4 & 9.9 & 145.3 & 0.2 & 14.3 & 11.3 & 105.7 & 1.4 & 30.3 & 16.6 & 200.8 & 1.8 \\
\hline Total particles $\left(\mu \mathrm{g} \mathrm{l}^{-1}\right)$ & 33.0 & 35.8 & 329.5 & 0.9 & 92.5 & 63.5 & 359.7 & 6.1 & 182.0 & 127.3 & 947.3 & 3.8 \\
\hline
\end{tabular}

Table 1. Descriptive statistics of density and biomass estimates for the major planktonic groups collected in Bryants Cove 


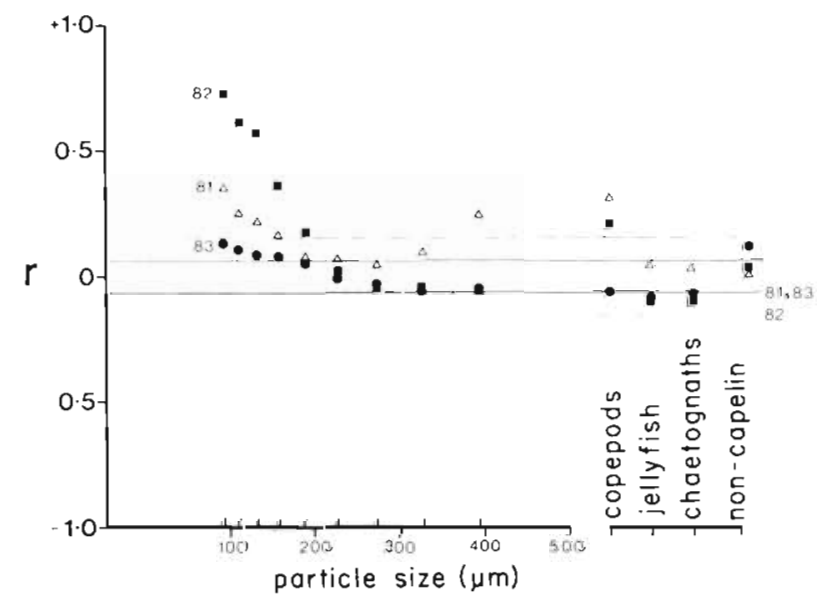

Fig. 2. Pearson correlation coefficient ( $r$ ) between capelin larvae density and major planktonic groups in individual collections for 3 уг in Bryants Cove. Significance levels $(p<0.01)$ for each year are denoted by solid $(1981, n=1634$; 1983, $\mathrm{n}=1622)$ and dashed $(1982, \mathrm{n}=283)$ lines

consistent decreasing trend in the correlation coefficients with increasing plankton particle size (up to $272 \mu \mathrm{m}$ esd) in all years. Larval density was positively and significantly correlated with copepod density in the $>750 \mu \mathrm{m}$ size-class in 1981 and 1982. Capelin density was also positively correlated with other noncapelin larvae and negatively correlated with chaetognath and jellyfish density in 1983. The edible particle size-class density and capelin density in all collections within each sampling survey were positively correlated in 71,83 and $71 \%$ of the surveys in 1981,82 and 83 respectively (Fig. 3). Although only $30 \%$ of the correlations were significantly positive the frequency distribution of the coefficients were negatively skewed. The time series of the correlation coefficients revealed no systematic variation with either temperature or wind velocity (Taggart \& Leggett 1987a), capelin abundance, particle abundance or copepod abundance.

\section{Large-scale associations}

Correlation analysis of the geometric average capelin density with the above plankton groups for each sampling survey (Fig. 4a) revealed results similar to the analysis of independent samples (Fig. 2). However, capelin density was significantly and decreasingly correlated with the 90,108, and $130 \mu \mathrm{m}$ esd plankton size-classes only in 1982 and 1983. Capelin were positively correlated with non-capelin larvae and negatively correlated with chaetognaths in both of 1982 and 1983. Capelin were also negatively correlated with jellyfish in 1983.

The correlations between capelin density and the other planktonic groups were partially explained by the correlation between water temperature (a good measure of water mass type; Taggart \& Leggett 1987) and the various groups (Fig. 4b). The 90, and $108 \mu \mathrm{m}$ esd particle size-classes and capelin larvae were positively and significantly correlated with temperature, and again a decreasing trend in the magnitude of the correlation coefficient from small to large plankton was apparent. Chaetognaths were negatively correlated with temperature in both years, whereas coefficients for jellyfish and copepods in the $>750 \mu \mathrm{m}$ size-class showed variation among years. There was no significant change in the correlation structures presented above when the data were assessed using Spearman-rank and Kendall-tau correlation analysis. This comparison of correlation analyses is consistent with the correlation analyses of other planktonic communities (Haury \& Wiebe 1982).

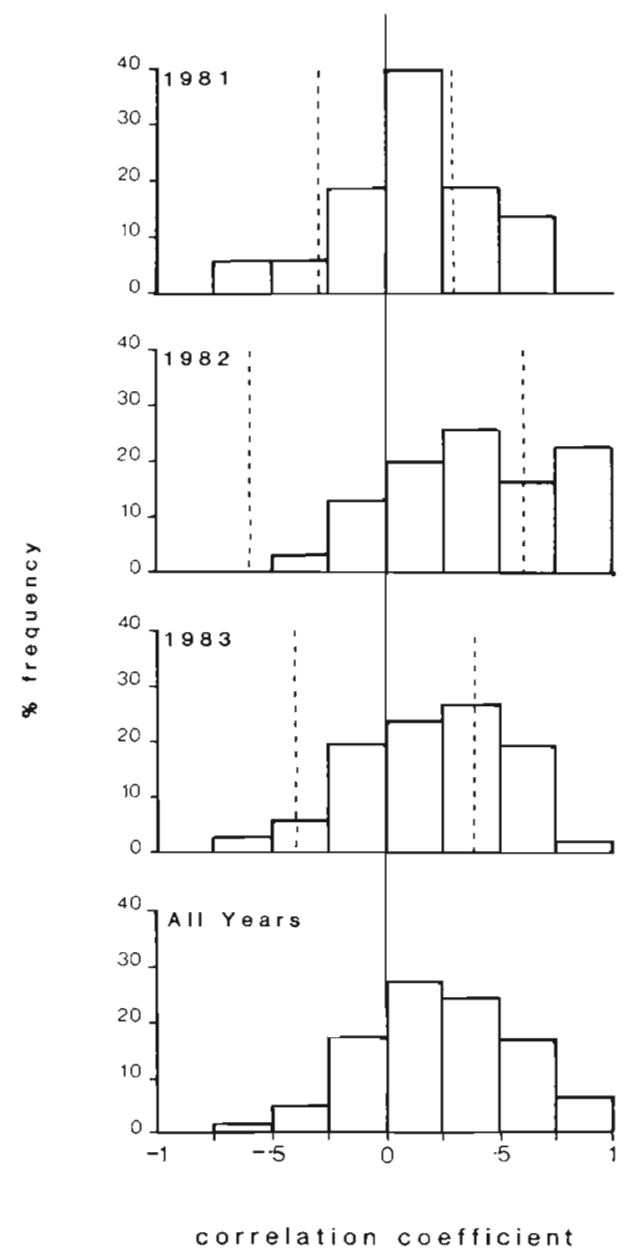

Fig. 3. Frequency histogram of Pearson correlation coefficients (r) between the abundance of capelin larvae and edible sizeclass particles (90 to $130 \mu \mathrm{m}$ esd) in independent collections $(\mathrm{n})$ taken during the 1 to $2 \mathrm{~h}$ sampling surveys $(\mathrm{N})$ in $1981(\mathrm{~N}=$ $38, \mathrm{n}=43), 1982(\mathrm{~N}=31$, average $\mathrm{n}=9), 1983(\mathrm{~N}=68$, average $n=24)$, and for all years combined $(N=137)$. Dashed lines indicate $95 \%$ significance level for $(n)$ in each year 

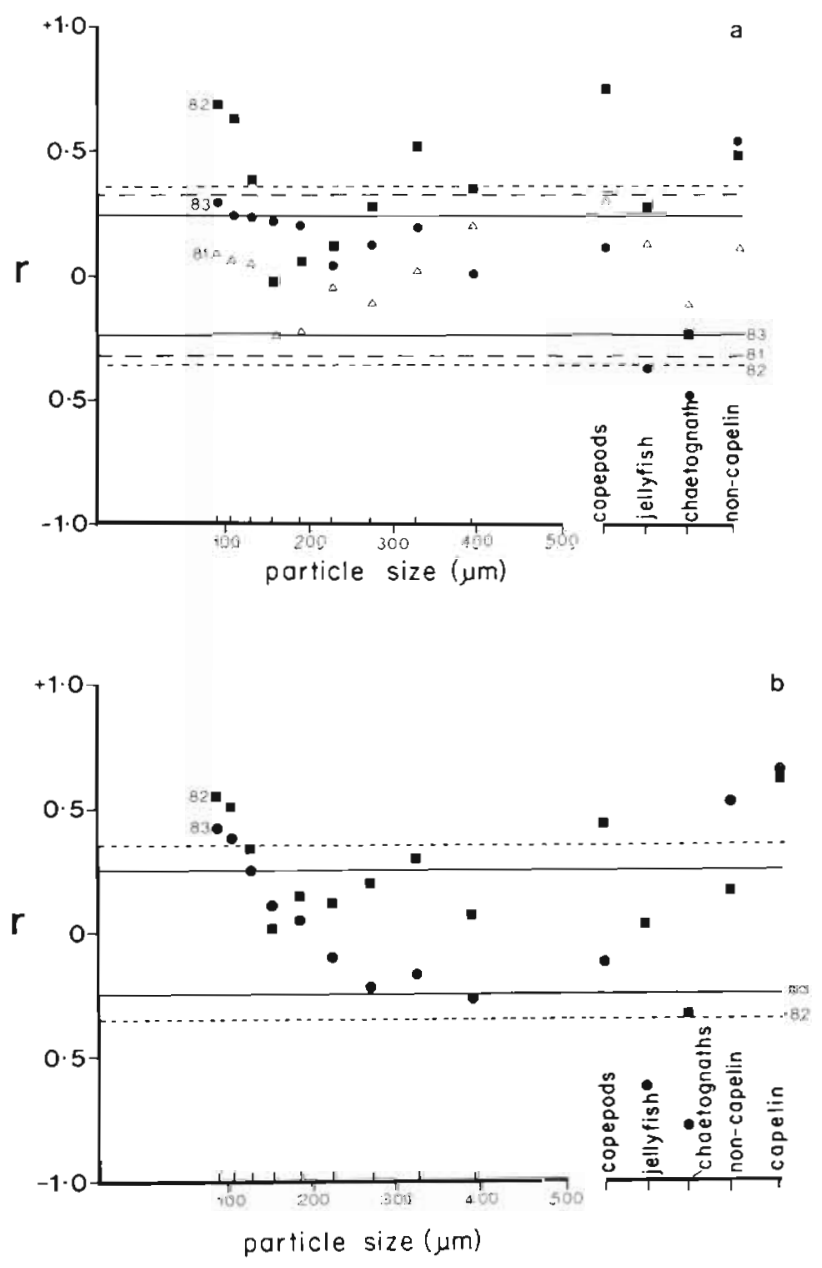

Fig. 4. Pearson correlation coefficient ( $\mathrm{r}$ ) between average density of capelin larvae (a) and temperature (b), and average density of various planktonic groups in each sampling survey for 3 yr in Bryants Cove. Significance levels $(p<0.05)$ for each year are denoted by dashed $(1981, \mathrm{n}=38 ; 1982, \mathrm{n}=31)$, and solid $(1983, n=68)$ lines. There were no temperature data in 1981

\section{Mortality correlates}

Correlation analysis between 36 biological variates (including density estimates of 11 macrozooplankton groups and 11 microzooplankton size-classes, $11 \mathrm{mi}$ crozooplankton size-class biomass estimates, larval immigration rate, and initial and final post-emergent larval density) with daily larval mortality $\left(\mathrm{M}_{5}\right)$ and instantaneous mortality $\left(z_{5}\right)$ from the combined 1982 and 1983 data revealed only crab megalop density to be marginally correlated with daily mortality $\left(\mathrm{r}^{2}=0.10, \mathrm{p}=\right.$ 0.043). This is far less than would be expected from chance alone at $\alpha_{0.05}$. The correlation between crab megalops density and mortality has little biological meaning because crab megalops were present in only 12 of the 99 sampling surveys in 1982 and 1983. Analysis of the data for each year independently yielded no significant correlates in the 1983 data $(n=28)$. In $1982(n=12)$ daily mortality was positively correlated $\left(\mathrm{r}^{2}=0.37, \mathrm{p}=\right.$ 0.036 ) with the immigration-emigration corrected larval density expected (NE), and with the rate of larval immigration from the beach $\left(r^{2}=0.52, p=0.008\right)$. These 2 correlations are consistent with the hypothesis of density-dependent mortality occurring in 1982.

The above correlation analyses were performed on the densities of the various planktonic groups expressed as the average of density estimates from sequential ( $t_{1}$ to $t_{2}$ ) sampling surveys (the beginning and the end of each sampling interval) which were used to estimate larval mortality. It was therefore reasonable to expect that the initial densities (at $t_{1}$ ) of the plankton groups would be more directly related to mortality, particularly as there were large changes in the densities of several groups between sequential estimates (Fig. 1). However, no significant correlates were identified when the analyses were repeated using the initial densities of the plankton groups. In the above analyses the densities of potential predators (jellyfish and chaetognaths) were positively correlated with capelin mortality, though never significantly. Examination of partial correlation coefficients provided no additional insight.

\section{Density-dependence}

There was no significant relation between $k$ (the logarithm of the density of surviving larvae) and log $\mathrm{NE}_{\mathrm{t}_{2}}$ in 1982 or 1983 or when the data from both years were combined (Fig. 5a, Table 2). Such a relation is a prerequisite to the demonstration of density-dependent mortality (Varley et al. 1973). Re-analysis with 2 (presumed to be anomalous) data values from 1983 removed resulted in a slight but insignificant improvement in the relation (Table 2). Nevertheless, we proceeded with the regression analysis of $\mathrm{N}_{t_{2}}$ (observed larval density) on $\mathrm{NE}_{\mathrm{t}_{2}}$ (expected larval density in the absence of mortality) and vice versa. This analysis resolved significant relations in both 1982 and 1983, and in both years combined (Fig. 5 b). However, only in 1982 and in both years combined, and only then with the presumed anomalous data points removed, were the slopes of $N_{t_{2}}$ on $N_{t_{2}}$ and $N_{t_{2}}$ on $N_{t_{2}}$ marginally different from 1.0 (Table 2 ) - the second requisite for a demonstration of density-dependent mortality. Only in 1982 were the slopes of the inversed regressions on the same side of $1: 1$ (i.e. $b>1.0$ and $1 / b^{\prime}>1.0$ ); the third requisite for demonstrating density-dependent mortality. 
Fig. 5. Relation between (a) $\mathrm{k}=\left(\log N E_{t_{1}}-N_{t_{2}}\right)$ and $\log N E_{l_{2}}$ and between (b) $\log \mathrm{N}_{\mathrm{t}_{2}}$ and $\log N \mathrm{~N}_{\mathrm{t}_{2}}$ for both $1982(\bullet)$ and 1983 () where immigration and emigration had been accounted for Open circles are the 2 'anomalous' data points not considered in one analysis
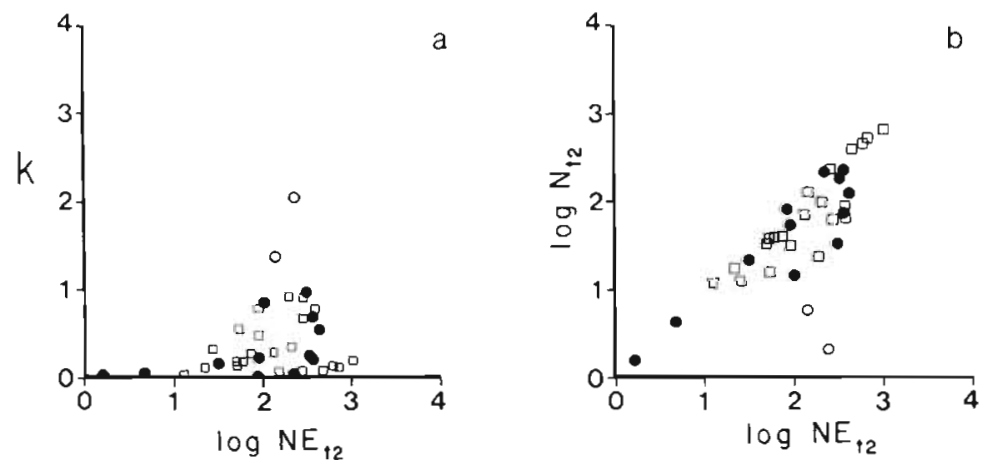

Table 2. Regression statistics from density-dependent mortality analysis providing sample size (n), significance based on the $\mathrm{F}$ statistic $(p>F)$, the coefficient of determination $\left(r^{2}\right)$, slope $(b)$, and the probability of the slope differing from $1.0(p[b=1.0])$

\begin{tabular}{|c|c|c|c|c|c|c|c|}
\hline Year & $\begin{array}{c}\text { Dependent } \\
\text { variable }\end{array}$ & $\begin{array}{l}\text { Independent } \\
\text { variable }\end{array}$ & $\mathrm{n}$ & $p>F$ & $r^{2}$ & b & $\mathrm{p}(\mathrm{b}=1.0)$ \\
\hline 1982 & $\begin{array}{c}K \\
\log N E_{t_{2}} \\
\log N_{t_{2}}\end{array}$ & $\begin{array}{l}\log \mathrm{NE}_{\mathrm{t}_{2}} \\
\log \mathrm{N}_{\mathrm{t}_{2}} \\
\log \mathrm{NE}_{\mathrm{t}_{2}}\end{array}$ & $\begin{array}{l}12 \\
12 \\
12\end{array}$ & $\begin{array}{l}0.0898 \\
0.0001 \\
0.0001\end{array}$ & $\begin{array}{l}0.261 \\
0.814 \\
0.814\end{array}$ & $\begin{array}{l}0.221 \\
1.045 \\
0.779\end{array}$ & $\begin{array}{r}<0.001 \\
0.780 \\
0.090\end{array}$ \\
\hline 1983 & $\begin{array}{c}K \\
\log N E_{t_{2}} \\
\log N_{t_{2}}\end{array}$ & $\begin{array}{l}\log N E_{t_{2}} \\
\log N_{t_{2}} \\
\log \mathrm{NE}_{t_{2}}\end{array}$ & $\begin{array}{l}28 \\
28 \\
28\end{array}$ & $\begin{array}{l}0.4591 \\
0.0001 \\
0.0001\end{array}$ & $\begin{array}{l}0.021 \\
0.433 \\
0.433\end{array}$ & $\begin{array}{l}0.144 \\
0.506 \\
0.856\end{array}$ & $\begin{array}{r}<0.001 \\
<0.001 \\
0.459\end{array}$ \\
\hline $\begin{array}{l}1982 \\
\text { and } \\
1983\end{array}$ & $\begin{array}{c}K \\
\log N E_{t_{2}} \\
\log N_{t_{2}}\end{array}$ & $\begin{array}{l}\log N E_{t_{z}} \\
\log N_{t_{z}} \\
\log N E_{t_{3}}\end{array}$ & $\begin{array}{l}40 \\
40 \\
40\end{array}$ & $\begin{array}{l}0.0968 \\
0.0001 \\
0.0001\end{array}$ & $\begin{array}{l}0.071 \\
0.559 \\
0.559\end{array}$ & $\begin{array}{l}0.197 \\
0.696 \\
0.804\end{array}$ & $\begin{array}{c}<0.001 \\
0.004 \\
0.098\end{array}$ \\
\hline $\begin{array}{l}1982 \\
\text { and } \\
1983^{\circ}\end{array}$ & $\begin{array}{c}\mathrm{K} \\
\log N E_{t_{2}} \\
\log \mathrm{N}_{\mathrm{t}_{2}}\end{array}$ & $\begin{array}{l}\log \mathrm{NE}_{\mathrm{t}_{2}} \\
\log \mathrm{N}_{\mathrm{t}_{2}} \\
\log \mathrm{NE}_{\mathrm{t}_{2}}\end{array}$ & $\begin{array}{l}38 \\
38 \\
38\end{array}$ & $\begin{array}{l}0.0592 \\
0.0001 \\
0.0001\end{array}$ & $\begin{array}{l}0.095 \\
0.745 \\
0.745\end{array}$ & $\begin{array}{l}0.160 \\
0.887 \\
0.840\end{array}$ & $\begin{array}{r}<0.001 \\
0.198 \\
0.059\end{array}$ \\
\hline
\end{tabular}

\section{DISCUSSION}

\section{Larvae and food associations}

The results of this study illustrated that post-emergent capelin larvae were associated with the abundance of food-sized plankton at large scales, but were not consistently associated at smaller scales. For all collections made within 1982 and 1983, the larvae and edible plankton particles were significantly and positively correlated, and the geometric averages of the 2 groups in each sampling survey were also significantly correlated in each year. These findings are consistent with those of Frank \& Leggett (1986). However, at the smallest resolvable scales (200 to $400 \mathrm{~m}$ horizontal, 2 to $4 \mathrm{~m}$ vertical, $2 \mathrm{~h}$ time) represented by each plankton sample collected in a single sampling survey, capelin larvae and the edible particle size-class were positively and significantly correlated in only $30 \%$ of the cases. The correlation coefficients were, however, positive in more than $70 \%$ of the cases.

These results demonstrate that as the time and space scales of sampling approach those relevant to the ambit of the larvae, the positive associations between microzooplankton and larvae become less defined. Houde \& Lovdal (1985), working at even smaller scales, found bay anchovy Anchoa mitchilli abundance not to be significantly correlated with microzooplankton abundance and concluded that the lack of association resulted from the near-random distribution of microzooplankton relative to the more contagious distribution of the larvae. Fluctuations in larval capelin and microzooplankton abundance in the St. Lawrence River were coincident only at long periods $(>12 \mathrm{~h}$ ) and at large scales $(>1 \mathrm{~km})$, and no association between larval capelin and microzooplankton abundance was identified at smaller scales (Courtois et al. 1982, Fortier \& Leggett 1984). The absence of small-scale (high frequency) association was also evident in the weak spectral coherence between the abundance of capelin larvae and microzooplankton in 1983 (Taggart \& Leggett 1987a). Although synchronous oscillations in microzooplankton and larval abundances were shown to occur in that study, the variations in abundances of the 2 taxa were not proportional. We conclude that there is no pronounced tendency for early drift capelin larvae 
to be coincident with microzooplankton at small scales $\left(<1 \mathrm{~km}_{\mathrm{i}}<12 \mathrm{~h}\right)$, either in water masses that are windforced (Bryants Cove), or in those that are tidally-forced (St. Lawrence River).

The findings reported here must be viewed in relation to the total plankton community and to the scale of the observations. The decreasing strength of correlations of larval abundance with increasing plankton particle size-classes at larger scales strongly suggest that the significant positive correlations are more than just chance events. Frank \& Leggett (1982) have noted that the warm surface waters advected shoreward during onshore winds stimulate the emergence of capelin larvae. This water is rich in the smaller edible zooplankton, and depauperate in larger zooplankton. The positive correlations identified in this study are consistent with the view that capelin larval emergence is an active response to a reliable largescale environmental cue and at this larger scale the larvae become associated with a 'safe site' (Frank \& Leggett 1983b, 1986).

\section{Mortality relationships}

Daily mortality estimates of post-emergent larval capelin $\left(\mathrm{M}_{5}\right)$ were neither significantly correlated with the density of the edible plankton size-classes (90 to $130 \mu \mathrm{m}$ esd), nor with the density estimates of other planktonic groups. These findings lead us to reject the hypothesis that short-term mortality in post-emergent larval capelin is related to the density of food (90 to $130 \mu \mathrm{m}$ esd) at scales of $1 \mathrm{~km}$ and 6 to $24 \mathrm{~h}$. This conclusion is important for 2 reasons. First, this is the first study where highly variable multiple short-term mortality estimates ( 3 to $100 \% \mathrm{~d}^{-1}$ ) have been obtained in the field with minimum sampling bias, and where edible plankton density was also highly variable 2 to 280 particles $1^{-1}$ ). Failure to find significant mortality correlates under these conditions argues for a reconsideration of the general hypothesis that early larval mortality is strongly food related (May 1974, Hunter 1981). However, it is entirely possible that variations in food abundance relative to the abundance of different subpopulations may influence sub-population mortality at a later stage. Lambert (1984) suggested that different larval cohorts may experience differential cumulative mortality over the full larval period so that only a few of many cohorts make significant contributions to recruitment. Lambert's hypothesis could explain why mortality estimates derived from most surveys do not effectively predict recruitment because of their large spatial and temporal scales.

Daily mortality was not significantly correlated with the abundance of potential predators (chaetognaths and jellyfish). However, because potential predator density was always positively correlated with mortality it is consistent with the hypothesis that predators regulate larval survival (May 1974, Hunter 1976, Möller 1980, Bailey 1984, Brewer et al. 1984). The positive trend is also consistent with the positions of Lambert (1984) and Hewitt et al. (1985) who argued that a sequencing of predator-induced and food-limited mortality contributes to the realized mortality during early larval development.

We view the above interpretation of trends in correlations with caution, not only for statistical reasons, but also because of the very nature of starvation and predation processes, and the potentially misleading inferences that may be drawn from a correlation analysis of abundance data that is collected near-instantaneously. Starvation is a continuous phenomenon projected over a relatively long period (days) which culminates in the loss of individuals from the population either through death and decomposition or though starvation-enhanced predation. Predator-induced losses are nearinstantaneous in their effect on population size, regardless of the health of the prey population. Therefore, when analysing mortality estimates that are determined near-instantaneously over very short intervals (as in this study), the probability of finding a correlation between mortality and a near-instantaneous effect (predation) is greater than the probability of finding an equivalent or stronger correlation between mortality and a cumulative effect (food limitation and starvation). This is particularly interesting because in Bryants Cove, and elsewhere, it has been demonstrated that the potential predator field does not overlap the immediate post-emergent larval field (Frank \& Leggett 1982, 1985), yet short-term mortality in this study tended toward a positive relation with the abundance of potential predators. The increased probability of finding a correlation between predator abundance and mortality will simply fuel the current interest in assessing predator impact on mortality (perhaps the proximate cause of mortality), in lieu of food limitation (perhaps the ultimate cause of mortality), even though the cumulative impact of predation may be slight relative to food limitation. The phenomenon could be assessed initially by testing the hypothesis that predation effects should be observed more frequently, relative to starvation effects, in larval fish species with a long starvation point-of-no-return, while larvae with short point-of-no-return starvation should more frequently be observed to suffer food-related mortality. It could also be assessed by the in situ tracking of a larval population and by coincidently sampling the larval population size and health, and its predator and prey fields over time in a manner similar to that employed by Shelbourne (1957) and Fortier \& Leggett (1985). 


\section{Density-dependent mortality}

Density-dependence did not appear important in explaining the observed mortality of post-emergent capelin larvae. This is an important result because the average densities of larval capelin observed varied by more than an order of magnitude, and the highest densities observed ( $>3000 \mathrm{~m}^{-3}$ in a single sample) were far greater than those frequently reported for marine fish larvae. Hence, if density-dependence was important during the immediate post-emergent period it should have been readily apparent. This does not mean that density-dependence may not be more readily observed or important at some later stages of development (Shepherd \& Cushing 1980, Cushing 1983), but its importance during the early drift stages appears to be minimal, or at best 'density vague' (Strong 1984).

\section{CONCLUDING REMARKS}

We have shown that adequate, unbiased, high resolution collections of larval fish, and their food can be made simultaneously (Taggart \& Leggett 1984). We have further demonstrated that the data derived from those collections can be successfully integrated and analysed along with the prevailing physical dynamics of the environment (Taggart \& Leggett 1987a). Subsequently, by using the multiple mortality estimates of larval capelin, corrected for immigration and emigration of individuals into and out of the target populations (Taggart \& Leggett 1987b), we have demonstrated that: (1) larvae and their prey were coherent in time and in space at scales of days and kilometers and that the coherence was largely determined by the physical dynamics of the environment (see Taggart \& Leggett 1987a); (2) at finer scales (ca $2 \mathrm{~h}, 200$ to $400 \mathrm{~m}$ ) the association between larval and prey densities was significantly reduced; (3) there was no significant relation between larval mortality and edible plankton sizeclasses which is consistent with (2) above; (4) there was no significant relation between larval mortality and the density of potential predators; and (5) there was no significant relation between larval mortality and larval density

The long-standing hypotheses relating food availability and density-dependence to the short-term mortality of larval fishes during early drift should be reconsidered because the time and space resolution of this study was greater than any previously achieved and was within the limits specified as necessary to resolve the relations sought (Smith 1978, Sharp 1980, Fortier \& Leggett 1985). Moreover, biases due to immigration and emigration, sampling, and the effects of behaviour and physical processes were minimized. This conclu- sion is consistent with the $70 \mathrm{yr}$ of studies that have repeatedly failed to provide unequivocal support for the hypotheses (May 1974, Leggett 1986).

Acknowledgements. This study was supported by grants to W. C. L. from the Natural Sciences and Engineering Research Council of Canada (NSERC) and the Canada Department of Fisheries and Oceans (DFO). C.T.T was supported by an NSERC post-graduate scholarship, the McConnell Foundation (McGill), and Group interuniversitaire de recherches océanographiques du Québec (GIROQ). We are grateful to J. Carscadden and DFO, St. John's, Nfld., J. Y Anctil and GIROQ, and N. Chalouhi, K. Tallon, J. C. Deguise, G. Maillet, M. Dolan, C. Gravel, G. Kerhuel, K. W. Frank, K. T. Frank, F. Juanez, and $D$. Webb for their expertise in the field and lab. We are grateful to the residents of Bryants Cove who gave us invaluable assistance on many occasions. We also thank $\mathrm{K}$. $\mathrm{T}$. Frank and $Y$. de Lafontaine for their comments, criticisms and advice during the design, execution, and analysis of the work and 3 anonymous reviewers who provided valuable criticisms and suggestions.

\section{LITERATURE CITED}

Anderson, J. T., Gardner, G. A. (1986). Plankton communities and physical oceanography observed on the Southeast Shoal region, Grand Bank of Newfoundland. J. Plankton Res. 8: 1111-1135

Arthur, D. K. (1976). Food and feeding of larvae of three fishes occurring in the California current, Sardinops sagax, Engraulis mordax, and Trachurus symmetricus. Fish. Bull. U. S. 74: 517-530

Bailey, K. M. (1981). Larval transport and recruitment of Pacific hake Merlucius productus. Mar. Ecol. Prog. Ser. 6: $1-9$

Bailey, K. M. (1984). Comparison of laboratory rates of predation of five species of marine fish larvae by three planktonic invertebrates: effects of larval size on vulnerability. Mar. Biol. 79: 303-309

Bakun, A., Parish, R. H. (1980). Environmental inputs to fishery population models for eastern boundary current regions. In: Sharp, G. D. (ed.) Workshop on the effects of environmental variation on survival of larval pelagic fishes. Intergovernmental Oceanographic Commission. Workshop Rep. No. 28, UNESCO, FAO, Rome, p. 67-104

Bjorke, H. (1976). Some preliminary results on food and feeding of young capelin larvae. Coun. Meet. int. Comm. Explor. Sea C.M. (ICES)/H: 37 (mimeo.) p. 1-12

Blaxter, J. H. S. (1963). The feeding of herring larvae and their ecology in relation to feeding. Calif. Coop. Fish. Invest. Rept 10: 79-88

Blaxter, J. H. S., Hempel, G. (1965). The influence of egg size on herring larvae. J. Cons. int. Explor Mer 28: 211-240

Brewer, G. D., Kleppel, G. S., Dempsey, M. (1984). Apparent predation on ichthyoplankton by zooplankton and fishes in nearshore water of southern California. Mar. Biol. 80: $17-28$

Chadwick, H. K., Stevens, D. E., Miller, L. W. (1977). Some factors regulating the striped bass population in the Sacramento-San Joaquin estuary, California. In: Van Winkle, $W$. (ed.) Assessing the effects of power plant-induced mortality on fish populations. Pergamon Press, New York, p. $18-35$

Crecco, V A., Savoy, T F. (1984). Effects of fluctuations in 
hydrographic conditions on year-class strength of American shad (Alosa sapidissima) in the Connecticut River Can. J. Fish. Aquat. Sci. 41. 1216-1223

Courtois, R., Simoneau, M., Dodson, J. J. (1982). Interactions multispécifiques: répartition spatio-temporelle des larves de capelan (Mallotus villosus), d'éperlan (Osmerus mordax) et de hareng d'Atlantique (Clupea harengus harengus) au sein de la communauté planctonique de l'estuaire moyen du Saint-Laurent. Can. J. Fish. Aquat. Sci. 39: 1164-1174

Cushing, D. H. (1966). Biological and hydrographic changes in British seas during the last thirty years. Biol. Rev. 41 $221-258$

Cushing, D. H. (1968). Fisheries biology: a study in population dynamics. Univ. Wisconsin Press, Madison

Cushing, D. H. (1972). The production cycle and the numbers of marine fish. Symp. Zool. Soc. Lond. 29: 213-232

Cushing, D. H. (1974a). The natural regulation of fish populations. In: Harden-Jones, F. R. (ed.) Sea fisheries research. Elek Science, London, p. 399-412

Cushing, D. H. (1974b). The possible density-dependence of larval mortality and adult mortality in fishes. In: Blaxter, $\mathrm{J}$ S. (ed.) The early life history of fish. Springer-Verlag, New York, p. 103-112

Cushing, D. H. (1983). Are fish larvae too dilute to affect the density of their food organisms? J. Plankton Res. 3 $847-854$

Cushing, D. H., Harris, J. G. K. (1973). Stock and recruitment and the problem of density-dependence. Rapp. P.-v. Réun. Cons int. Explor. Mer 164: 142-155

Dementyeva, T.F. (1958). Methods of studying the effect of environmental factors on the fluctuations in abundance of the Azov anchovy. Trudy V. N. I. R. O. 34:30-62

Fortier, L., Leggett, W. C. (1984). Small-scale covariability in the abundance of fish larvae and their prey. Can. J. Fish. Aquat. Sci. 41: 502-512

Fortier, L., Leggett, W. C. (1985). A drift study of larval fish survival. Mar. Ecol. Prog. Ser. 25: 245--257

Frank, K. T. (1986). Ecological significance of the ctenophore Pleurobrachia pileus off southwestern Nova Scotia. Can. J. Fish. Aquat. Sci. 43: 211-222

Frank, K. T. (1988). Independent distributions of fish larvae and their prey: natural paradox or sampling artifact. Can. J. Fish. Aquat. Sci. (in press)

Frank, K. T., Leggett, W. C. (1982). Coastal water mass replacement: its effect on zooplankton dynamics and the predator-prey complex associated with larval capelin (Mallotus villosus). Can. J. Fish. Aquat. Sci. 39: 991-1003

Frank, K. T., Leggett, W. C. (1983a). Multispecies larval fish associations: accident or adaptation? Can. J. Fish. Aquat. Sci. 40: $754-762$

Frank, K. T., Leggett, W C. (1983b). Survival value of an opportunistic life stage transition in capelin (Mallotus villosus). Can. J. Fish. Aquat. Sci. 40: 1442-1448

Frank, K. I., Leggett, W. C. (1985). Reciprocal oscillations in densities of larval fish and potential predators: a reflection of present or past predation. Can. J. Fish. Aquat. Sci. 42 : $1841-1849$

Frank, K. T., Leggett, W. C. (1986). Effect of prey abundance and size on growth and survival of larval fish: an experimental study employing large volume enclosure. Mar Ecol. Prog. Ser. 34: 1.1-22

Fraser, J. H. (1970). The ecology of the ctenophore Pleurobrachia pileus in Scottish waters. J. Cons. int. Explor. Mer 33: $149-168$

Gadomski, D. M., Boehlert, G. W (1984). Feeding ecology of pelagic larvae of English sole (Parophrys vetuJus) and butter sole (Isopsetta isolepis) off the Oregon coast. Mar. Ecol Prog. Ser 20: 1-12

Grauman, G. B. (1973). Investigations of factors influencing fluctuations in abundance of Baltic cod. Rapp. P.-v. Réun. Cons. int. Explor. Mer 164: 73-76

Harding, D., Talbot, J. W. (1973). Recent studies on the eggs and larvae of the plaice (Pleuronectes platessa L.) in the Southern Bight. Rapp. P-v. Réun. Cons. int. Explor. Mer 164: $261-269$

Harris, J. G. K. (1975). The effect of density-dependent mortality on the shape of the stock recruitment curve. J. Cons. int. Explor. Mer 36: 144-149

Haury, L. R., Wiebe, P. H. (1982). Fine-scale multi-species aggregations of oceanic zooplankton. Deep Sea Res. 29: 915-921

Hempel, G. (1963). The causes of changes in recruitment. Rapp. P.-v. Réun. Cons. int. Explor. Mer 154 (Annex II): $17-22$

Hempel, G. (1965). On the importance of larval survival for the population dynamics of marine food fish. Calif. Coop. Fish. Invest. Rept 10: 13-23

Hewitt, R. P., Teilacker, G. H., Lo, N. C. H. (1985). Causes of mortality in young jack mackerel. Mar. Ecol. Prog. Ser. 26: $1-10$

Hjort, J. (1914). Fluctuations in the great fisheries of northern Europe viewed in the light of biological research. Rapp. P.v. Réun. Cons. int. Explor. Mer 20: 1-228

Hjort, J. (1926). Fluctuations in the year classes of important food fishes. J. Cons. int. Explor. Mer 1: 5-38

Houde, E. D. (1978). Critical food concentrations for larvae of three species of subtropical marine fishes. Bull. mar. Sci. 28: $395-411$

Houde, E. D., Lovdal, J. A. (1984). Seasonality of occurrence, foods and food preferences of ichthyoplankton in Biscayne Bay, Florida. Estuar. coast. Shelf Sci. 18: 403-419

Houde, E. D., Lovdal, J. A. (1985). Patterns of variability in ichthyoplankton occurrence and abundance in Biscayne Bay, Florida. Estuar. coast. Shelf Sci. 20: 79-103

Hunter, J. R. (1972). Swimming and feeding behavior of larval anchovy Engraulis mordax. Fish. Bull. U. S. 70: 821-838

Hunter, J. R. (1976). Report of a colloquium on larval fish mortality studies and their relation to fishery research, January 1975. U. S. Dept. Commer. NOAA Tech. Rept Nat. Mar. Fish. Ser. Circ. 395: 1-5

Hunter, J. R. (1981). Feeding ecology and predation of marine fish lárvae. In: Lasker, R. (ed.) Marine fish larvae. University of Washington Press, Seattle, p. 33-77

Iles, T D., Sinclair, M. (1982). Atlantic herring: stock discreteness and abundance. Science 215: 627-633

Jones, R. (1973). Density-dependent regulation of cod and haddock. Rapp. P.-v. Réun. Cons. int. Explor. Mer 164 $156-173$

Jones, R., Hall, W. B. (1974). Some observations on the population dynamics of the larval stage in some common gadoids In: Blaxter, J. S. (ed.) The early life history of fish Springer-Verlag, New York, p. 87-102

Kane, J. (1984). The feeding habits of co-occurring cod and haddock larvae from Georges Bank. Mar. Ecol. Prog. Ser. 1.6: $9-20$

Lambert, I C. (1984). Larval cohort succession in herring (Clupea harengus) and capelin (Mallotus villosus). Can. J. Fish. Aquat. Sci. 41: 1552-1564

Lasker, R. (1975). Field criteria for the survival of anchovy larvae: the relation between inshore chlorophyll maximum layers and successful first feeding. Fish. Bull. U. S. 73: $453-462$

LeBrasseur, R. J., Barraclough, W. E., Kennedy, O. D., Parsons, 
T. R. (1969). Production studies in the Strait of Georgia. Part III. Observations on the food of larval and juvenile fish in the Fraser River plume, February to May, 1967. J. exp. mar Biol. Ecol. 39: 51-61

Leggett, W. C. (1977). Density-dependence, density-independence, and recruitment in the American shad (Alosa sapidissima) population of the Connecticut River In: Van Winkle, W. (ed.) Assessing the effects of power plantinduced mortality on fish populations. Pergamon Press, New York, p. 3-17

Leggett, W. C. (1986). The dependence of fish larval survival on food and predator densities. In: Skreslet, S. (ed.) The role of freshwater outflow in coastal marine ecosystems. NATO ASI series G, Vol. 7. Springer-Verlag, Berlin, p. $117-137$

Leggett, W C., Frank, K. T., Carscadden, J. E. (1984). Meteorological and hydrographic regulation of year-class strength in capelin Mallotus villosus. Can. J. Fish. Aquat. Sci. 41. 1193-1201

May, R. C. (1974). Larval mortality in marine fishes and the critical period concept. In: Blaxter, J. S. (ed.) The early life history of fish. Springer-Verlag, New York, p. 3-19

Möller, H. (1980). Scyphomedusa as predators and food competitors of larval fish. Meeresforschung 28: 90-100

Murphy, G. I. (1961). Oceanography and variations in the Pacific sardine population. Calif. Coop. Fish. Invest. Rept 8: $55-64$

Nelson, W., Ingham, M. C., Schaaf, W. E. (1977). Larval transport and year-class strength of Atlantic menhaden, Brevoortia tyrannus. Fish. Bull. U. S. 75: 23-42

O'Boyle, R. N., Sinclair, M., Conover, R. J., Mann, K. H., Kohler, A. C. (1984). Temporal and spatial distribution of ichthyoplankton communities of the Scotian Shelf in relation to biological, hydrological, and physiographic features. Rapp. P.-v. Réun. Cons. int. Explor. Mer 183: $27-40$

O'Connell, C. P. (1980). Percentage of starving northern anchovy (Engraulis mordax) larvae in the sea as estimated by histological methods. Fish Bull. U.S. 78: 475-489

O'Connell, C. P., Raymond, L. P. (1970). The effect of food density on survival and growth of early post yolk-sac larvae of the northern anchovy (Engraulis mordax Girard) in the laboratory. J. exp. mar Biol. Ecol. 5: 187-197

Peterman, R. M., Bradford, M. J. (1987). Wind speed and mortality rate of a marine fish, the northern anchovy (Engraulis mordax). Science 235: 354-356

Peterson, W. T., Ausubel, S. J. (1984). Diets and selective feeding by larvae of Atlantic mackerel Scomber scombrus on zooplankton Mar. Ecol. Prog. Ser, 17: 65-75

Rosenberg, A. A., Haugen, A. S. (1982). Individual growth and size-selective mortality of larval turbot (Scophthalmus maximus) reared in enclosures. Mar. Biol. 72: 73-77

Rosenthal, H., Hempel, G. (1971). Experimental estimates of minimum food density for herring larvae. Rapp. P.-v. Réun. Cons. int. Explor Mer 160: 125-127

Rothschild, B. J. (1986). Dynamics of marine fish populations. Harvard Univ. Press, Cambridge, Massachusetts

Sharp. G. D. (1980). Report of the workshop on effects of environmental variation on survival of larval pelagic fishes. In: Sharp, G. D. (ed.) Workshop on the effects of environmental variation on the survival of larval pelagic fishes. Intergovernmental Oceanographic Commission, Workshop Rep. No. 28. UNESCO, FAO, Rome, p. 15-63

Shelbourne, J. E. (1957). The feeding and condition of plaice larvae in good and bad plankton patches. J. mar. biol. Ass. U. K. 36: 539-552

Shepherd, J. G., Cushing, D. H. (1980). A mechanism for density-dependent survival of larval fish as a basis of a stock-recruitment relationship. J. Cons. int. Explor. Mer 39: $160-167$

Sinclair, M., Tremblay, M. J., Bernal, P. (1985). El Niño events and variability in a Pacific mackerel (Scomber japonicus) survival index: support for Hjort's second hypothesis. Can. J. Fish. Aquat. Sci. 42: 602-608

Swissenwine, M. P. (1984). Why do fish populations vary? In: May, R. M. (ed.) Exploitation of marine communities. Dahlem Konferenzen, Berlin. Springer-Verlag, Berlin, p. $59-94$

Smith, P. E. (1978). Biological effects of ocean variability: time and space scales of biological response. Rapp. P.-v. Réun. Cons. int. Explor. Mer 173: 117-127

Soleim, P. A. (1942). Årsaker til rike og fattige årganger av sild. FiskDir. Skr. Ser. HavUnders. 7: 1-39

Southwood, T.R.E. (1978). Ecological methods. Chapman and Hall, London

Strong, D. R. (1984). Density-vague ecology and liberal population regulation in insects. In: Price, P. W. Slobodchikoff, C. N., Gaud, W. S. (ed.) A new ecology. Wiley, New York, p. $313-328$

Taggart, C. T., Leggett, W. C. (1984). Efficiency of largevolume plankton pumps, and evaluation of a design suitable for deployment from small boats. Can. J. Fish. Aquat. Sci. 41: 1428-1435

Taggart, C. T., Leggett, W C. (1987a). Wind-forced hydrodynamics and their interaction with larval fish and plankton abundance: a time-series analysis of physical-biological data. Can. J. Fish. Aquat. Sci. 44: 438-451

Taggart, C. T., Leggett, W. C. (1987b). Short-term mortality in post-emergent larval capelin Mallotus villosus. I. Analysis of multiple in situ estimates. Mar. Ecol. Prog. Ser 41: 205-217

Theilacker, G. H. (1986). Starvation-induced mortality of young sea-caught jack mackerel, Trachurus symmetricus, determined with histological and morphological methods. Fish. Bull. U. S. $84: 1-17$

Varley, G. C., Gradwell, G. R. (1960). Key factors in population studies. J. Anim, Ecol. 29: 399-401

Varley, G. C., Gradwell, G. R., Hassell, M. P. (1973). Insect population ecology, an analytical approach. Blackwell, Oxford

Vilela, M. H., Zijlstra, J. J. (1971). On the condition of herring larvae in the central and southern North Sea. Rapp. P.-v. Réun. Cons. int. Explor Mer 160: 137-141

Waldmann, J. (1961). Untersuchungen an Heringslarven und Zooplankton des Greifswalder Boddens in den Jahren 1958 und 1959. Z. Fisch. 10: 523-536

Walline, P. D. (1985). Growth of larval walleye pollock related to domains within the SE Bering Sea. Mar. Ecol. Prog. Ser. 21: $197-203$

Ware, D. M. (1975). Relation between egg size, growth, and natural mortality of larval fish. J. Fish. Res. Bd Can. 32: 2503-2512

Ware, D. M., Lambert, T C. (1985). Early life history of Atlantic mackerel (Scomber scombrus) in the southern Gulf of St. Lawrence. Can. J. Fish. Aquat. Sci. 42: 577-592

Wiborg, Kr. Fr. (1976). Larval mortality in marine fishes and the critical period concept. J. Cons. int. Explor. Mer 37: 111

Wroblewski, J. S. (1984). Formulation of growth and mortality of larval northern anchovy in a turbulent feeding environment. Mar. Ecol. Prog. Ser. 20: 13-22

This article was presented by Dr G. C. Harding; it was accepted for printing on September 15, 1987 